\title{
Antidiabetic Activity of the Compounds Isolated From Rhus Mysorensis Plant Extract
}

\author{
Ganji Renuka rani* ${ }^{1,2}$, Singara Charya $\mathrm{MA}^{2}$, M. Viswanadham ${ }^{1}$, \\ Murali Krishna Thupurani ${ }^{3}$ \\ 1. Department of Environmental Science and technology, JNTU, Hyderabad \\ 2. Department of Microbiology, Kakatiya University, Warangal, India. \\ ${ }^{3}$. Department of Biotechnology, Chaitanya PG. College (Autonomous), Kakatiya University, Warangal, India.
}

\begin{abstract}
The current study was framed to evaluate the anti diabetic activity of falvonoids isolated from the leaves and rhizomes of Rhus mysorensis. Anti diabetic effects of these flavonoids were screened using in vitro and in vivo models. The in vitro anti diabetic activity was screened using enzyme assay. The in vivo anti diabetic activity was screened in albino diabetic induced rats. The inhibition of $\alpha$-amylase and $\alpha$-glucosidase by the isolated compounds were found in concentration dependent manner. The high inhibition was found at 150 $\mathrm{mg} / \mathrm{mL}$ concentration. Among the compounds screened, 2-(3,4-dihydroxyphenyl)-hydroxy-4H-chromen-4-one and 5,6,7-trihydroxy-2-phenyl-4H-chromen-4-one showed significant enzyme inhibitory effects. the fasting blood glucose levels are increased 0 hour to 7 days of treatment. Animals of the groups VII, VIII, IX, XIII, XIV, $X V$ (Diabetic control +2-(3,4-dihydroxyphenyl)-hydroxy-4H-chromen-4-one and 5,6,7-trihydroxy-2-phenyl4H-chromen-4-one at 100,150,200 mg/mL) significant reduction in the blood glucose levels after prolonged treatment $(P<0.001)$. we noticed that compounds 2-(3,4-dihydroxyphenyl)-hydroxy-4H-chromen-4-one and 5,6,7-trihydroxy-2-phenyl-4H-chromen-4-one started to reduce the glucose levels significantly from 14 days of treatment was comparable to blood glucose levels of animals treated with standard drug glibenclamide.
\end{abstract}

Keywords: falvonoids, glibenclamide, Rhus mysorensis, $\alpha$-amylase, $\alpha$-glucosidase

\section{Introduction}

In more recent history the use of plants as medicines has involved the isolation of active compounds involves in the development of plant derived drugs ${ }^{[1]}$. There are several bioactive compounds isolated from the plants are currently in clinical trials are extensively use as Ayurvedic medicine for the treatment of diabetic mellitus ${ }^{[2]}$. Approximately, 108 plant species belonging to 56 families and 400 plants derived compounds are playing a major role in delaying diabetic complications ${ }^{[3-4]}$. Diabetes has been identified as an oxidative stress based disorder generated by an imbalance between the cellular production of reactive oxygen species and the counteracting antioxidant mechanisms by body's natural antioxidants ${ }^{[5]}$. Studies have suggested that oxidative stress are enacted in systemic inflammation, endothelial dysfunction, impaired secretion of pancreatic $\beta$-cells and glucose utilization in peripheral tissues that lead to long-term secondary complications ${ }^{[6]}$.

The current study was framed to evaluate the anti diabetic activity of falvonoids isolated from the leaves and rhizomes of Rhus mysorensis (Data of compound isolation was not shown here). "Rhus mysorensis" "Rhous ancient Greek name for sumac, the genus Rhus refers to various shrubs or small trees. A small aromatic, often gregarious shrub with a thin brown bark and very spinous branches, Leaves trifoliate or rarely Penta foliate branch lets woolly at apices, spines up to $1.5 \mathrm{~cm}$ long. Leaf arrangement Alternate Spiral Leaf Shape Obovate Leaf apex Obtuse-apiculate often emarginated Leaf Base - Cuneate. Leaf Margin - sinous. It is found in dry slopes and exposed rocks from 400 to $800 \mathrm{mts}$ common in India Grow on stony regions, found in hot dry places in Punjab, Haryana, Rajasthan, Gujarat, Karnataka, Andhraprades, Telangana and the Western Peninsula, Common in foot hills, Scrub jungles to $900 \mathrm{~m}$. North west India to the peninsular India. Anti diabetic effects of these flavonoids were screened using in vitro and in vivo models. The in vitro anti diabetic activity was screened using enzyme assay. The in vivo anti diabetic activity was screened in albino diabetic induced rats ${ }^{[7]}$.

2.1 Anti-diabetic Activity

\section{Material And Methods}

2.1.1 In vitro enzyme inhibitory effects Rhus mysorensis crude extracts

a. Alpha-amylase inhibitory activity

Alpha amylase (EC 3.2.1.1) inhibitory activities of compounds isolated from Rhus mysorensis extracts was determined according to the method described by elsewhere with slight modification ${ }^{[8]}$. Briefly $0.25 \mu 1$ of urinary alpha amylase $(5 \mathrm{U} / \mathrm{ml})$ was pre-incubated with various concentrations $(50,75,100,125,150 \mu \mathrm{g} / \mathrm{mL})$ of isolated compounds for $15 \mathrm{~min}$ at $37^{\circ} \mathrm{C}$ water bath. The reaction was started by addition of $0.2 \mu \mathrm{l}$ of $0.5 \%$ potato starch dissolved in $20 \mathrm{mM}$ phosphate buffer, $\mathrm{pH}$ 6.9. The reaction mixture was then incubated at $37^{\circ} \mathrm{C}$ for 20 
minutes and terminated by addition of $2.0 \mathrm{ml}$ of DNS reagent (1\% 3,5-dinitrosalicylic acid, $12 \%$ sodium potassium tartrate in $0.4 \mathrm{M} \mathrm{NaOH}$ ). The reaction mixture was heated for $15 \mathrm{~min}$ at $100^{\circ} \mathrm{C}$. Amylase activity was determined by measuring the absorbance at $540 \mathrm{~nm}$ and expressed as percentage of the blank control (without the extract).

\section{b. Alpha glucosidase inhibitory activity}

The effect of the plant extracts on alpha glucosidase activity was determined according to the chromogenic method described by by elsewhere ${ }^{[8]}$. The substrate solution p-nitrophynyl glucopyranoside (pNPG) was prepared in $20 \mathrm{mM}$ phosphate buffer, pH 6.9. Five units of alpha glucosidase (E.C. 3.2.1.20) were pre-incubated with various concentrations $(50,75,100,125,150 \mu \mathrm{g} / \mathrm{mL})$ of flavonoids isolated from leaves and rhizome extract of Rhus mysorensis for 15 minutes. Three millimolar (pNPG) as a substrate dissolved in $20 \mathrm{mM}$ phosphate buffer, $\mathrm{pH} 6.9$ was then added to start the reaction. The reaction mixture was incubated at $37^{\circ} \mathrm{C}$ for 20 minutes and stopped by adding $2 \mathrm{ml}$ of $0.1 \mathrm{M} \mathrm{Na}_{2} \mathrm{CO}_{3}$. The $\alpha$-glucosidase activity was determined by measuring the yellow colored p-nitrophenol released from pNPG at $400 \mathrm{~nm}$. The results were expressed as percentage of the blank control.

\subsubsection{In vivo anti-diabetic activity}

Registration of Establishment with CPCSEA-Committee for the Purpose of Control and Supervision of Experiments on Animals; All the experiments on animals are carried out according to breeders under Rule 5(a) of the "Breeding of and Experiments on Animals (control and Supervision) Rules 1998". The animal experiments are carried according to the guidelines of CPCSEA. The registration number is 768/03/ac/CPCSEA.

\subsubsection{Induction of diabetes}

Streptozotocin was purchased from Sisco Research laboratories Pvt. Ltd. Mumbai, India and was freshly dissolved in $0.1 \mathrm{M}$ citrate buffer $(\mathrm{pH}=4.5)$ at the dose of $50 \mathrm{mg} / \mathrm{kg}$ body weight and injected intraperitoneally within 15 min of dissolution in a vehicle volume of $0.4 \mathrm{ml}$ with $1 \mathrm{ml}$ of tuberculin syringe fitted with 24 gauge needle, whereas normal control group was given citrate buffer only $(0.4 \mathrm{ml})$. Diabetes was confirmed by the determination of fasting glucose concentration on the third day post administration of streptozotocin

\subsubsection{Body weight}

Each animal was weighed daily using mouse balance (Adventurer SL, Switzerland), for the period of four weeks which the experiment lasted. After 28 days of treatment, experiments were terminated and observations were noted.

\subsubsection{Effects on blood glucose levels}

At the end of the experiment the blood (1 ml) was collected from the orbital sinus into heparin coated bottles and immediately used for the determination of glucose using a glucometer (Vivek et al., 2007).

Experimental design for the anti diabetic effects of the isolated compounds in albino rats

\begin{tabular}{|c|c|c|}
\hline S.No & *Group & Treatment \\
\hline 1 & $\mathbf{I}$ & Rats in this group which served as normal control and were given only distilled water daily \\
\hline 2 & II & $\begin{array}{l}\text { Rats in this group are STZ induced diabetic rats and served as diabetic control and were given distilled } \\
\text { water only }\end{array}$ \\
\hline 3 & III & $\begin{array}{l}\text { Rats of this group are STZ induced and were treated orally with glibenclamide used as a reference drug } \\
\text { and was administered orally at } 4 \mathrm{mg} / \mathrm{kg} \text { as a suspension in } 1 \% \mathrm{w} / \mathrm{v} \text { CMC daily for } 28 \text { days, once in a day. }\end{array}$ \\
\hline 4 & IV & $\begin{array}{l}\text { Rats of this group are STZ induced diabetic rats and were treated orally with } \mathbf{2 - ( 3 , 4 - d i h y d r o x y p h e n y l ) -} \\
\text { 3,5,7-trihydroxy-4H-chromen-4-one at the dose of } 100 \mathrm{mg} / \mathrm{kg} \text { body weight daily for } 28 \text { days, once a } \\
\text { day. }\end{array}$ \\
\hline 5 & $\mathbf{V}$ & $\begin{array}{l}\text { Rats of this group are STZ induced diabetic rats and were treated orally with 2-(3,4-dihydroxyphenyl)- } \\
3,5,7 \text {-trihydroxy- } 4 H \text {-chromen-4-one at the dose of } 150 \mathrm{mg} / \mathrm{kg} \text { body weight daily for } 28 \text { days, once a day. }\end{array}$ \\
\hline 6 & VI & $\begin{array}{l}\text { Rats of this group are STZ induced diabetic rats and were treated orally with 2-(3,4-dihydroxyphenyl)- } \\
3,5,7 \text {-trihydroxy- } 4 H \text {-chromen-4-one at the dose of } 200 \mathrm{mg} / \mathrm{kg} \text { body weight daily for } 28 \text { days, once a day }\end{array}$ \\
\hline 7 & VII & $\begin{array}{l}\text { Rats of this group are STZ induced diabetic rats and were treated orally with } \mathbf{2 - ( 3 , 4 - d i h y d r o x y p h e n y l ) -} \\
\text { hydroxy- } \mathbf{H} \text {-chromen-4-one at the dose of } 100 \mathrm{mg} / \mathrm{kg} \text { body weight daily for } 28 \text { days, once a day. }\end{array}$ \\
\hline 8 & VIII & $\begin{array}{l}\text { Rats of this group are STZ induced diabetic rats and were treated orally with 2-(3,4-dihydroxyphenyl)- } \\
\text { hydroxy- } 4 \mathrm{H} \text {-chromen-4-one at the dose of } 150 \mathrm{mg} / \mathrm{kg} \text { body weight daily for } 28 \text { days, once a day. }\end{array}$ \\
\hline 9 & IX & $\begin{array}{l}\text { Rats of this group are STZ induced diabetic rats and were treated orally with 2-(3,4-dihydroxyphenyl)- } \\
\text { hydroxy- } 4 \mathrm{H} \text {-chromen-4-one at the dose of } 200 \mathrm{mg} / \mathrm{kg} \text { body weight daily for } 28 \text { days, once a day. }\end{array}$ \\
\hline 10 & $\mathbf{X}$ & $\begin{array}{l}\text { Rats of this group are STZ induced diabetic rats and were treated orally with } \mathbf{2 - ( 3 , 4 - d i h y d r o x y p h e n y l ) - ~} \\
\text { 3,7-dihydroxy-4H-chromen-4-one at the dose of } 100 \mathrm{mg} / \mathrm{kg} \text { body weight daily for } 28 \text { days, once a day. }\end{array}$ \\
\hline 11 & XI & $\begin{array}{l}\text { Rats of this group are STZ induced diabetic rats and were treated orally with 2-(3,4-dihydroxyphenyl)- } \\
3,7 \text {-dihydroxy- } 4 H \text {-chromen-4-one at the dose of } 150 \mathrm{mg} / \mathrm{kg} \text { body weight daily for } 28 \text { days, once a day. }\end{array}$ \\
\hline
\end{tabular}




\begin{tabular}{|l|l|l|}
\hline $\mathbf{1 2}$ & XII & $\begin{array}{l}\text { Rats of this group are STZ induced diabetic rats and were treated orally with 2-(3,4-dihydroxyphenyl)- } \\
\text { 3,7-dihydroxy-4H-chromen-4-one at the dose of } 200 \mathrm{mg} / \mathrm{kg} \text { body weight daily for 28 days, once a day. }\end{array}$ \\
\hline $\mathbf{1 3}$ & XIII & $\begin{array}{l}\text { Rats of this group are STZ induced diabetic rats and were treated orally with 5,6,7-trihydroxy-2-phenyl- } \\
\mathbf{4 H} \text {-chromen-4-one at the dose of } 100 \mathrm{mg} / \mathrm{kg} \text { body weight daily for 28 days, once a day. }\end{array}$ \\
\hline $\mathbf{1 4}$ & XIV & $\begin{array}{l}\text { Rats of this group are STZ induced diabetic rats and were treated orally with 5,6,7-trihydroxy-2-phenyl- } \\
4 H \text {-chromen-4-one at the dose of } 150 \mathrm{mg} / \mathrm{kg} \text { body weight daily for 28 days, once a day. }\end{array}$ \\
\hline $\mathbf{1 5}$ & $\mathbf{X V}$ & $\begin{array}{l}\text { Rats of this group are STZ induced diabetic rats and were treated orally with 5,6,7-trihydroxy-2-phenyl- } \\
4 H \text {-chromen-4-one at the dose of } 200 \mathrm{mg} / \mathrm{kg} \text { body weight daily for 28 days, once a day. }\end{array}$ \\
\hline
\end{tabular}

\section{Results}

\subsection{Inhibitory activities of isolated compounds on $\alpha$-amylase and $\alpha$-glucosidase}

The inhibition of $\alpha$-amylase and $\alpha$-glucosidase by the isolated compounds were found in concentration dependent manner. The high inhibition was found at $150 \mathrm{mg} / \mathrm{mL}$ concentration. Among the compounds screened, 2-(3,4-dihydroxyphenyl)-hydroxy-4H-chromen-4-one and 5,6,7-trihydroxy-2-phenyl-4Hchromen-4-one showed significant enzyme inhibitory effects. The highest $\alpha$-amylase and $\alpha$-glucosidase inhibition percentage noted at $150 \mathrm{mg} / \mathrm{mL}$ by the compounds $\mathbf{2 - ( 3 , 4 - d i h y d r o x y p h e n y l ) - h y d r o x y - 4 H}$-chromen4-one and 5,6,7-trihydroxy-2-phenyl-4H-chromen-4-one is 79.8, 77.7, 77.1, 74.1 respectively (Graph 1-4). Compounds 2-(3,4-dihydroxyphenyl)-3,5,7-trihydroxy-4H-chromen-4-one, 2-(3,4-dihydroxyphenyl)-3,7dihydroxy- $\mathbf{H} \boldsymbol{H}$-chromen-4-one showed moderate anti diabetic activities by inhibiting the enzymes $\alpha$-amylase and $\alpha$-glucosidase.

\subsection{Measurement of body weight of animals}

At the termination period (28 days), we have determined the body weight of animals. During our studies, we observed that animas of all groups (I-XV expect group-II- diabetic control) showed remarkable weight gain (Table 1). Animals related to the groups VII, VIII, IX, XIII, XIV, XV (Diabetic control +2-(3,4dihydroxyphenyl)-hydroxy-4H-chromen-4-one and 5,6,7-trihydroxy-2-phenyl-4H-chromen-4-one at 100 , $150,200 \mathrm{mg} / \mathrm{mL}$ ) gained their body weight significantly $80 \%$ compared with that from animals of remaining groups. The results are compared with standard drug glibenclamide. Animals treated with only glibenclamide gained their body weight by $84 \%$. Animals of group II (diabetic control) showed the body weight of $56 \%$ (lost their body weight by14\%.) Animals of group I (Normal control) have been consistent in their body weight (Table 1).

\subsection{Determination of blood Glucose levels}

According to data shown in table 2, the fasting blood glucose levels are increased 0 hour to 7 days of treatment. Animals of the groups VII, VIII, IX, XIII, XIV, XV (Diabetic control +2-(3,4-dihydroxyphenyl)-hydroxy-4Hchromen-4-one and 5,6,7-trihydroxy-2-phenyl-4H-chromen-4-one at 100, $150,200 \mathrm{mg} / \mathrm{mL})$ significant reduction in the blood glucose levels after prolonged treatment $(\mathrm{P}<0.001)$. we noticed that compounds $\mathbf{2}-\mathbf{( 3 , 4 -}$ dihydroxyphenyl)-hydroxy-4H-chromen-4-one and 5,6,7-trihydroxy-2-phenyl-4H-chromen-4-one started to reduce the glucose levels significantly from 14 days of treatment was comparable to blood glucose levels of animals treated with standard drug glibenclamide. The results are found in concentration manner. The hiher concentrations of compounds 2-(3,4-dihydroxyphenyl)-hydroxy-4H-chromen-4-one and 5,6,7-trihydroxy-2phenyl-4H-chromen-4-one reduced the glucose levels of $80 \%(151.8 \pm 1.1$ and $153.2 \pm 1.7$ at $150 \mathrm{mg} / \mathrm{mL})$. Animals of group III (Positive control) showed consistent decrease in the blood glucose levels by $95 \%$ comparing to the blood glucose levels of normal control rats. On the other hand, there is decrease in the blood glucose levels of group II (Diabetic control) (Table 2).

\section{Discussion}

In the present study, we have demonstrated the anti diabetic activities of flavonoids isolated from Rhus mysorensis (isolation data was not shown). The screening was performed in in vitro and in vivo anti diabetic methods. The in vitro anti diabetic assay was carried out using enzyme assay. The in vivo anti diabetic activity was done in diabetic induced albino rats. During our studies, we observed that, among four flavonoids tested, two are more significantly showed enzyme inhibition and lowered the blood glucose levels and comparable to the standard drug showed for a period of 4 weeks. It clear noted that, these flavonoids possess a common mechanism for the inhibition of both enzymes because of structural similarities of both enzymes ${ }^{[9]}$. Another mechanism exhibited by the compounds that delay or inhibit the mechanism of digestion [10]. Antihyperglycemic activities of compounds tested in streptozoticin induced rats showed good activity on reduction of blood glucose levels. Initially, body weight and glucose levels of animals were found to be increased till the 7th day after streptozotocin administration and thereafter, from 7th day, we noticed a drastic decrease in blood glucose levels of animals treated with treated with compounds with various concentrations. On the other hand body weight of animals also shown in increase. In concern to hazardous effects shown by synthetic drugs the naturally derived drugs gained movement to replace the chemically derived drugs. Therefore, scientists 
increased focused for isolation of naturacetuicals which are safe and affordable. Contemporary compounds isolated from plants which are currently use as anti diabetic drugs are salacinol, kotalanol, glucoside jamboline, phytol, myoinositol, scyllitol, pryones, stigmat-4-en-3-one, cholest-4-en-3-one. These compounds exhibit different modes of action that include inhibition of intestinal amylase- $\alpha$-glucosidase, increase of $\beta$-cell stimulation, increase in number of insulin receptors, increase in insulin receptor binding affinity to the released insulin, fighting against free radicals to decrease cell damage and decrease of hepatic glucose by decreasing gluconeogenesis and glycogenolysis ${ }^{[1]}$. By the literature of survey, we found that, the crude root extracts of Rhus mysorensis showed consequential antidiabetic activity in wister rats by decreased the blood glucose levels ${ }^{[12]}$. Till the date we don't found only little literature on anti diabetic activities of crude extracts or isolated compounds from the Rhus mysorensis. Therefore, here under we consider the anti diabetic activities of other species of Rhus family. Rhus coriaria, chirindensis, verniciflua crude extracts reported to possess significant In vitro and In vivo hypoglycemic activities ${ }^{[13-15]}$. The results of this report could become the first reports on the anti diabetic activity of flavonoids isolated from the Rhus mysorensis.

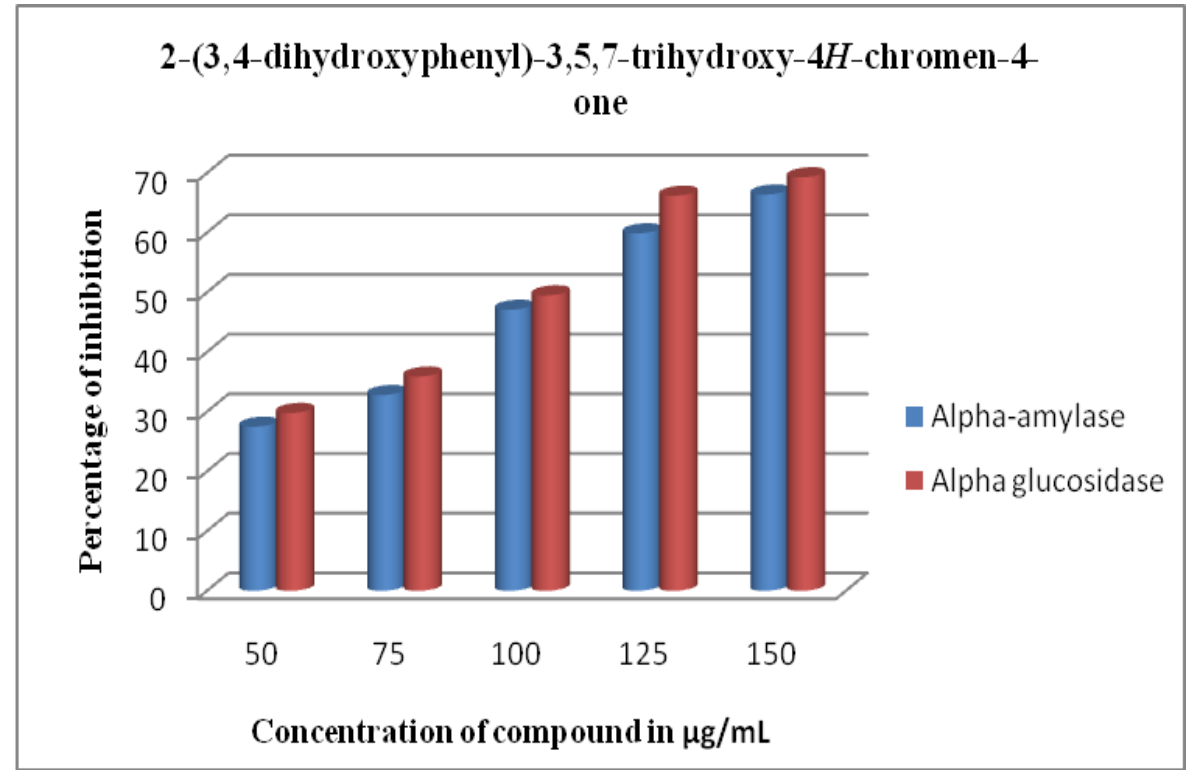

Graph-1: In vitro anti diabetic effects of flavonoid 2-(3,4-dihydroxyphenyl)-3,5,7-trihydroxy-4H-chromen-4one Isolated from Rhus mysorensis crude extracts

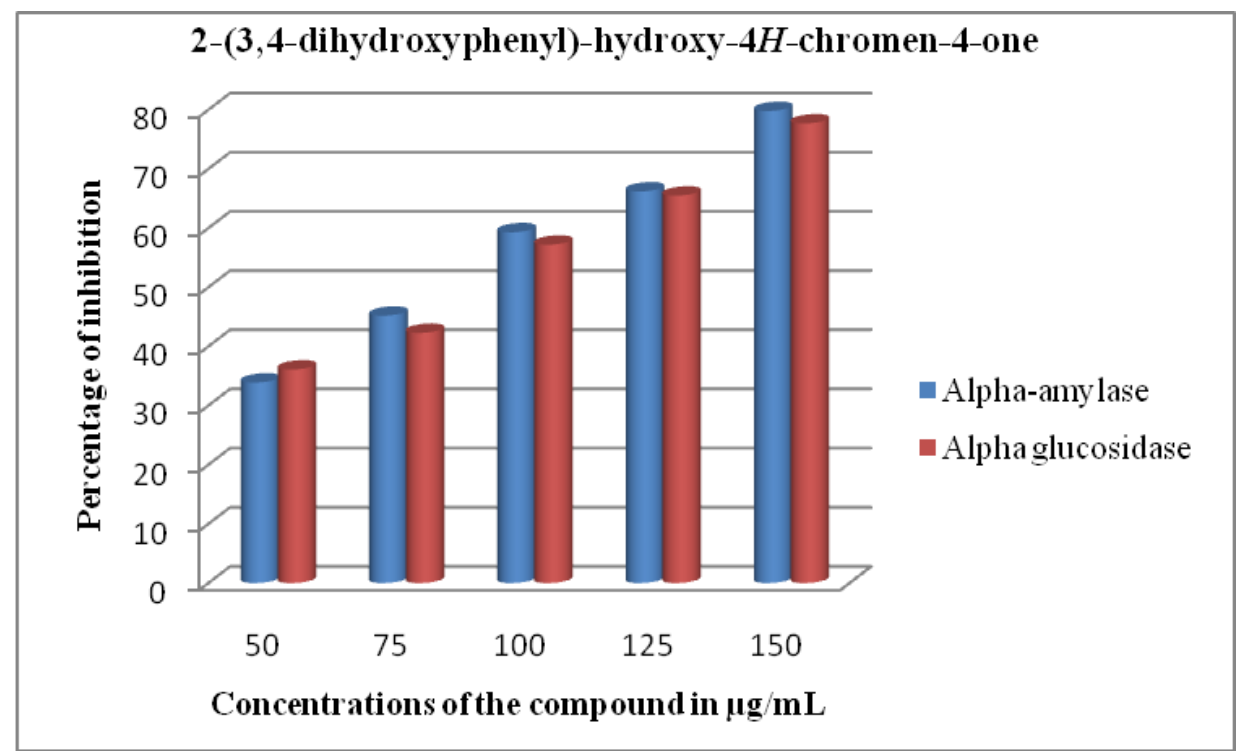

Graph-2: In vitro anti diabetic effects of flavonoid 2-(3,4-dihydroxyphenyl)-hydroxy-4H-chromen-4-one Isolated from Rhus mysorensis crude extracts 


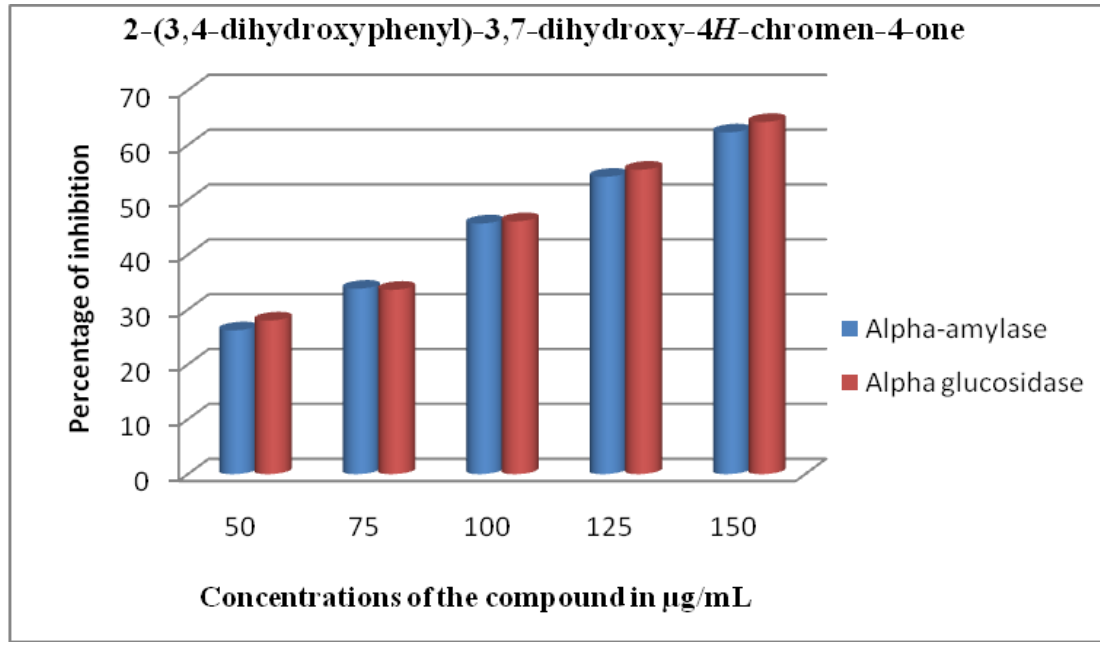

Graph-3: In vitro anti diabetic effects of flavonoid 2-(3,4-dihydroxyphenyl)-3,7-dihydroxy-4H-chromen-4-one Isolated from Rhus mysorensis crude extracts

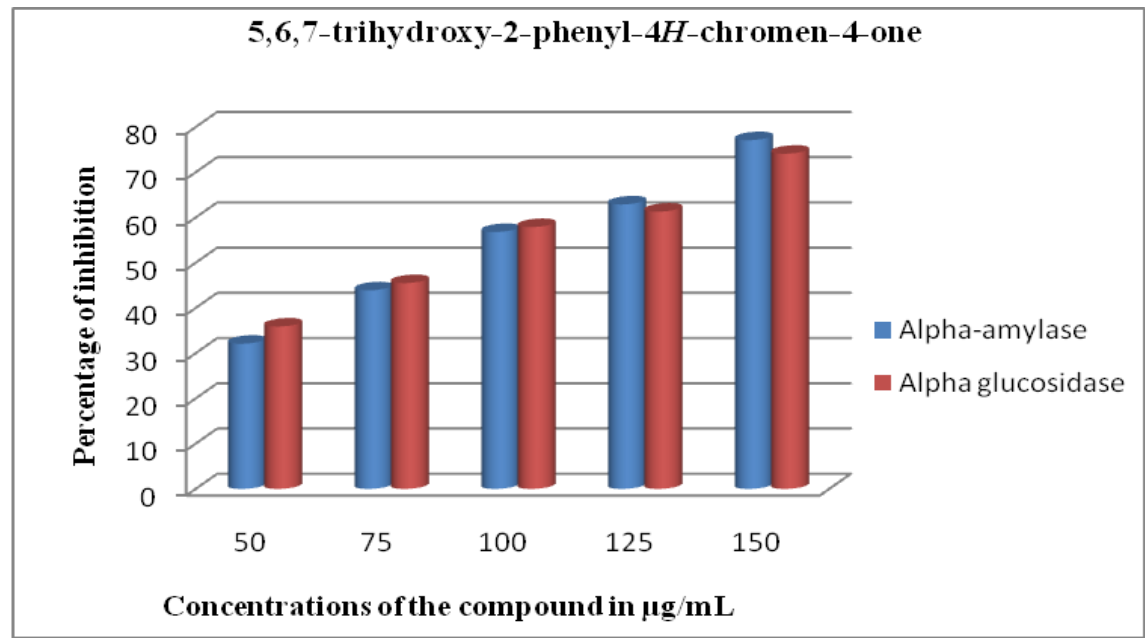

Graph-4: In vitro anti diabetic effects of flavonoid 5,6,7-trihydroxy-2-phenyl-4H-chromen-4-one Isolated from Rhus mysorensis crude extracts

Table 1: Body weight measurement $(\mathrm{SEM} \pm \mathrm{SD})$ of streptozotocin-induced Wistar rats during four weeks of treatment with isolated compounds from Rhus mysorensis crude extract

\begin{tabular}{|l|l|l|l|l|l|}
\hline & \multicolumn{5}{|c|}{ Days in Number } \\
\cline { 2 - 6 } & \multicolumn{1}{|c|}{$\mathbf{0 ~ h o u r}$} & \multicolumn{1}{|c|}{$\mathbf{7}^{\text {th }}$ Day } & \multicolumn{1}{|c|}{$\mathbf{1 4}^{\text {th }}$ Day } & $\mathbf{2 1}^{\text {st }}$ Day $^{\text {Day }}$ \\
\hline Normal & $232.1 \pm 0.2$ & $232 \pm 0.9$ & $232 \pm 1.0$ & $232 \pm 0.5$ & $232 \pm 1.3$ \\
\hline +ve Control (Diabetic) & $232.5 \pm 0.1$ & $191.4 \pm 0.5$ & $173.1 \pm 0.5$ & $151.6 \pm 0.1$ & $129.2 \pm 0.5$ \\
\hline Compound-1(100 mg/Kg) & $232.2 \pm 0.8$ & $194.0 \pm 1.2$ & $199.8 \pm 0.3$ & $203.3 \pm 1.2$ & $207.5 \pm 0.1$ \\
\hline Compound-1(150 mg/Kg) & $232.4 \pm 0.2$ & $199.2 \pm 1.6$ & $204.2 \pm 1.1$ & $208.5 \pm 0.8$ & $213.3 \pm 0.1$ \\
\hline Compound-1(200 mg/Kg) & $232.9 \pm 0.1$ & $203.2 \pm 0.4$ & $208.1 \pm 1.5$ & $213.0 \pm 0.4$ & $216.8 \pm 1.3$ \\
\hline Compound-2(100 mg/Kg) & $232.5 \pm 0.5$ & $193.5 \pm 0.1$ & $200.8 \pm 0.6$ & $208.1 \pm 1.3^{\text {a }}$ & $217.6 \pm 1.6^{\text {a }}$ \\
\hline Compound-2(150 mg/Kg) & $232.2 \pm 0.3$ & $194.3 \pm 1.1$ & $202.1 \pm 0.1$ & $210.6 \pm 1.9^{\text {a }}$ & $221.4 \pm 1.1^{\text {a }}$ \\
\hline Compound-2(200 mg/Kg) & $232.1 \pm 0.7$ & $200.5 \pm 0.9$ & $212.0 \pm 1.1$ & $222.6 \pm 1.1^{\text {a }}$ & $231.8 \pm 1.0^{\text {a }}$ \\
\hline Compound-3 (100 mg/Kg) & $232.9 \pm 0.3$ & $191.9 \pm 1.5$ & $195.2 \pm 1.3$ & $199.8 \pm 0.2$ & $201.6 \pm 0.8$ \\
\hline Compound-3 (150 mg/Kg) & $232.8 \pm 0.2$ & $194.0 \pm 1.3$ & $199.1 \pm 0.5$ & $204.5 \pm 1.5$ & $210.3 \pm 1.0$ \\
\hline Compound-3 (200 mg/Kg) & $23204 \pm 1.1$ & $198.2 \pm 1.0$ & $205.6 \pm 0.1$ & $211.1 \pm 1.0$ & $217.2 \pm 0.9$ \\
\hline Compound-4 (100 mg/Kg) & $232.8 \pm 1.2$ & $196.2 \pm 0.8$ & $204.5 \pm 0.9$ & $213.0 \pm 1.4^{\text {a }}$ & $220.5 \pm 1.1^{\text {a }}$ \\
\hline Compound-4 (150 mg/Kg) & $232.2 \pm 1.0$ & $200.4 \pm 1.2$ & $206.2 \pm 1.8$ & $214.1 \pm 1.7^{\text {a }}$ & $222.0 \pm 1.3^{\text {a }}$ \\
\hline Compound-4 (200 mg/Kg) & $232.0 \pm 0.1$ & $203.1 \pm 1.6$ & $212.5 \pm 0.5$ & $220.7 \pm 1.5^{\text {a }}$ & $228.3 \pm 1.1^{\text {a }}$ \\
\hline +ve Control ( glibenclamide) & $232.3 \pm 0.3$ & $200.5 \pm 0.9$ & $216.4 \pm 1.3$ & $225.2 \pm 0.5$ & $233.5 \pm 0.6$ \\
\hline
\end{tabular}

${ }^{\mathrm{a}} \mathrm{p}<0.001$ of isolated compounds compared with that from Body weight of normal animals and diabetic control

Compound 1; 2-(3,4-dihydroxyphenyl)-3,5,7-trihydroxy-4H-chromen-4-one, Compound 2; 2-(3,4dihydroxyphenyl)-hydroxy-4H-chromen-4-one

Compound 3; 2-(3,4-dihydroxyphenyl)-3,7-dihydroxy-4H-chromen-4-one, Compound 4; 5,6,7trihydroxy-2-phenyl- $4 H$-chromen-4-one 
Antidiabetic activity of the compounds isolated from Rhus mysorensis plant extract

Table 2: Fasting blood glucose $(\mathrm{SEM} \pm \mathrm{SD})$ of streptozotocin-induced diabetes in Wistar rats during four weeks of treatment with isolated compounds from Rhus mysorensis crude extract

\begin{tabular}{|c|c|c|c|c|c|}
\hline \multirow{2}{*}{$x^{2}$} & \multicolumn{5}{|c|}{ Days in Number } \\
\hline & 0 hour & $7^{\text {th }}$ Day & $14^{\text {th }}$ Day & $21^{\text {st }}$ Day & $28^{\text {th }}$ Day \\
\hline Normal & $98.15 \pm 1.2$ & $98.72 \pm 0.9$ & $98.05 \pm 1.5$ & $98.21 \pm 0.5$ & $98.63 \pm 1.1$ \\
\hline -ve Control (Diabetic) & $221.5 \pm 1.0$ & $229.6 \pm 1.1$ & $240.9 \pm 1.4$ & $251.2 \pm 1.0$ & $260.8 \pm 1.2$ \\
\hline Compound-1(150 mg/mL) & $220.2 \pm 1.3$ & $212.7 \pm 1.2$ & $200.9 \pm 0.2$ & $193.1 \pm 1.0$ & $187.3 \pm 0.7$ \\
\hline Compound-1(200 mg/mL) & $220.5 \pm 1.1$ & $202.1 \pm 1.5$ & $193.6 \pm 2.0$ & $186.2 \pm 0.5$ & $179.5 \pm 1.9$ \\
\hline Compound-2(100 mg/mL) & $221.9 \pm 1.0$ & $212.2 \pm 0.3$ & $200.5 \pm 1.1$ & $193.1 \pm 1.6^{\mathrm{a}}$ & $185.6 \pm 1.0^{\mathrm{a}}$ \\
\hline Compound-2(200 mg/mL) & $220.3 \pm 1.0$ & $196.2 \pm 1.1$ & $182.6 \pm 1.0$ & $166.1 \pm 1.2^{\mathrm{a}}$ & $151.8 \pm 1.1^{\mathrm{a}}$ \\
\hline Compound-3 (100 mg/mL) & $223.4 \pm 1.8$ & $212.1 \pm 0.5$ & $201.5 \pm 1.5$ & $192.1 \pm 1.1$ & $184.3 \pm 0.1$ \\
\hline Compound-3 (150 mg/mL) & $222.7 \pm 0.5$ & $204.6 \pm 1.6$ & $195.6 \pm 0.8$ & $187.1 \pm 0.1$ & $180.7 \pm 1.0$ \\
\hline Compound-3 (200 mg/mL) & $220.5 \pm 1.4$ & $200.1 \pm 1.8$ & $192.3 \pm 1.0$ & $183.4 \pm 1.2$ & $177.2 \pm 0.3$ \\
\hline Compound-4 $(100 \mathrm{mg} / \mathrm{mL})$ & $223.8 \pm 1.0$ & $214.3 \pm 0.2$ & $203.6 \pm 1.0$ & $195.1 \pm 0.2^{\mathrm{a}}$ & $188.4 \pm 1.2^{\mathrm{a}}$ \\
\hline Compound-4 $(150 \mathrm{mg} / \mathrm{mL})$ & $221.2 \pm 1.3$ & $201.5 \pm 1.5$ & $194.2 \pm 0.5$ & $178.3 \pm 1.1^{\mathrm{a}}$ & $164.2 \pm 1.0^{\mathrm{a}}$ \\
\hline
\end{tabular}

${ }^{\mathrm{a}} \mathrm{p}<0.001$ of isolated compounds compared with that from glucose levels of normal animals and diabetic control.

Compound 1; 2-(3,4-dihydroxyphenyl)-3,5,7-trihydroxy-4H-chromen-4-one, Compound 2; 2-(3,4-

dihydroxyphenyl)-hydroxy-4H-chromen-4-one

Compound 3; 2-(3,4-dihydroxyphenyl)-3,7-dihydroxy-4H-chromen-4-one, Compound 4; 5,6,7-trihydroxy-2phenyl-4H-chromen-4-one

\section{Conclusion}

Basing on our studies, we conclude that the compounds isolated from the Rhus mysorensis exhibit the anti diabetic activity tested in vitro and in vivo. However, the further studies are required to use these compounds to treat for the various forms of diabetic mellitus.

\section{Acknowledgement}

The authors sincerely thank to the Dr. A. Thirupatiah, Assistant Professor, Natural Products Laboratory, Chaitanya Degree and PG College (Autonomous), for his valuable suggestions during extraction and performing the activity.

\section{References}

[1] SD Sarker, Pharmacognosy in modern pharmacy curricula, Pharmacogn Mag, 8(30), 2012, 91-92.

[2] DK Patel, SK Prasad, R Kumar, S Hemalatha, An over view on anti-diabetic medicinal plants havening insulin mimetic property, Asian Pac J Trop Biomed, 25(4), 2012, 320-330.

[3] ANMM Rashid, Md Shamim Hossain, N Hassan, B Dash Kumar, Md. Ashrafuzzaman Sapon, M Kumer Sen, A review on medicinal plants with antidiabetic activity, Journal of Pharmacognosy and Phytochemistry, 3(4), 2014, 149-159.

[4] CL, Chang, Y Lin, AP Bartolome, YC Chen, SC Chiu, WC Yang, Herbal therapies for type 2 diabetic mellitus: Chemistry, Biology and Potential applications of selected plants and compounds, Evid Based Complement Alternat med, (2013), 378657,1-33.

[5] S Salim, Oxidative stress and psychological disorders, Curr. Neuropharmacol, 12 (2), 2014, 140-147.

[6] SR Zatalia, H Sanusi, The role of antioxidants in the pathophysiology, complications, and management of diabetes mellitus, Acta Med. Indones, 45(2), 2013, 141-147.

[7] G Aparna, Agnihotri, Roopali Raghavan, Sudha Premnath., "Field Guide to Shrubs," 2012.

[8] YM Kim, YK Jeong, MH Wang, WY Lee, HI Rhee, Inhibitory effects of pine bark extract on alpha-glucosidase activity and postprandial hyperglycemia, Nutrition, 21(6), 2005, 756-761.

[9] MI Ochiai, T Nakayama, R Goto, M Nakao, T Ueda, Y Shibano, Altering substrate specificity of bacillus sp. Sam1606 alpha glucosidase by comparative site-specific mutagenesis, Journal of Biology and Chemistry, 272 (3), 1997, 1601-1607.

[10] Z Madar, The effect of acarbose and miglitol (bay-m-1099) on postprandial glucose levels following ingestion of various sources of starch by nondiabetic and streptozotocin-induced diabetic rats, Journal of Nutrition, 119 (12), 1989, 2023-2029.

[11] KGK Deepak, N Nageswara Rao Reddy, C Surekha, Role of Antidiabetic Compounds on Glucose Metabolism - A Special Focus on Medicinal Plant: Salacia sps. Med chem 4(1), 2014, 373-381.

[12] SM Lamba, K Sulakhiya, Parveen Kumar. Anti-diabetic, Hypolipidemic and Anti-oxidant Activities of Hydroethanolic Root Extract of Rhus Mysurensis Heyne in Streptozotocin Induced Diabetes in Wistar Male Rats, Phcog J. 6(3), 2014, 62-71.

[13] S Giancarlo, LM Rosa, F Nadjafi, M Francesco, Hyperglycemic activity of two species extracts: Rhus coriaria L and Bunium persicum boiss, Natural Product Research, 20(9), 2006, 882-886.

[14] JA Ojewole, Analgesic, Anti-inflammatory and Hyperglycemic effects of Rhus chirindensis (Baker F.) [Anacardiaceae] stem bark aqueous extract in mice and rats, Journal of Ethanophormacology, 113 (2), 2007, 338-348.

[15] CH Jung, S Zhou, GX Ding, JH Kim, MH Hong, YC Shin GJ Kim, SG Ko, Anti-hyperglycemic activity of herb extracts on streptozotocin induced diabetic rats. Bioscience, Biotechnology and Biochemistry, 70(10), 2006, 2556-2559.

IOSR Journal of Biotechnology and Biochemistry (IOSR-JBB) is UGC approved Journal with Sl. No. 4033, Journal no. 44202.

Ganji Renuka Rani. "Antidiabetic Activity of the Compounds Isolated From Rhus Mysorensis Plant

Extract." IOSR Journal of Biotechnology and Biochemistry (IOSR-JBB) 3.3 (2017): 37-42.

L-- - - - - - - - - $10.9790 / 264$ X 03033742 